\title{
Acute Porphyria Presenting as Epilepsia Partialis Continua
}

\author{
Thi Phuoc Yen Tran $^{a} \quad K^{2}$ arine Leduc ${ }^{b} \quad$ Martin Savard $^{b} \quad$ Nicolas Dupréb \\ Donald Rivest $^{c}$ Dang Khoa Nguyen ${ }^{a}$ \\ ${ }^{a}$ Service de Neurologie, Hôpital Notre-Dame, Centre Hospitalier Universitaire de \\ Montréal, Montréal, Qué., 'Service de Neurologie, Hôpital de l'Enfant-Jésus, Centre \\ Hospitalier Universitaire de Québec, and ' Service de Neurologie, Hôpital Hôtel-Dieu de \\ Lévis, Centre Hospitalier Universitaire de Québec, Québec City, Qué., Canada
}

\section{Key Words}

Acute porphyria · Status epilepticus · Epilepsia partialis continua

\begin{abstract}
Purpose: The porphyrias are a defect in the biosynthesis of heme which can be associated with different neurological symptoms during acute attacks such as peripheral neuropathy, mental disturbance and seizures. So far, there have only been a few case reports of status epilepticus, none of which were of epilepsia partialis continua (EPC). We present here two cases of hereditary coproporphyria (HCP) manifesting EPC as part of the clinical presentation. Method: The patients' medical charts, EEG and imaging studies were carefully reviewed. Results: Case 1 is a 49-year-old male who first presented a tonic-clonic seizure. Case 2 is a 30-year-old male who came to the emergency room for a convulsive status epilepticus. Both evolved to EPC over the next days. EPC persisted despite several antiepileptic drug trials. Diagnosis of HCP was confirmed by a high level of urine, fecal and serum porphyrins in both cases and by genetic testing in one. Over the last 3 years, the first patient has continued to present non-disabling EPC and has had four tonic-clonic seizures associated with alcohol consumption. The second patient died from brain edema one month and half after admission. Conclusion: Acute porphyrias should be included in the differential diagnosis of new onset status epilepticus, including EPC. Their recognition is important as it modifies significantly patient management, since many anticonvulsants are porphyrogenic.
\end{abstract}

(C) 2013 S. Karger AG, Basel 
Tran et al.: Acute Porphyria Presenting as Epilepsia Partialis Continua

\section{Introduction}

The porphyrias, a group of disorders characterized by a variable catalytic defect of one of the seven enzymes in the biosynthesis of heme, are classified clinically as acute or nonacute porphyrias based on their clinical manifestations with or without neurovisceral attacks [1-3]. The major manifestations of acute porphyrias are neurological, including neuropathic abdominal pain, peripheral neuropathy, mental disturbance and seizures. Seizures affect $10-20 \%$ of patients with acute porphyria [1]. The most commonly reported types of seizures are complex partial seizures and tonic-clonic seizures [4, 5], even though EEG documentation of such seizures have been sparse. Status epilepticus has also been rarely reported. Here, we report two patients with hereditary coproporphyria (HCP) who presented with status epilepticus and an EEG documentation.

\section{Case Summaries}

Case 1

A 49-year-old right-handed man with a past medical history of Berger's disease presented to the emergency room on December 13, 2009, for a 1-min-long tonic-clonic seizure and increasing confusion over the past week. He was immediately started on acyclovir and phenytoin. The initial EEG, brain MRI and lumbar puncture were normal. Within 2 days, he developed continuous right hand myoclonic jerks compatible with epilepsia partialis continua (EPC). Repeat brain MRI performed 3 days after admission disclosed nonenhancing high T2 and FLAIR signal changes over the bilateral temporal lobes (fig. 1). Brain PET revealed focal hypermetabolism over the bilateral frontal and temporal lobes, predominantly over the left side. Repeat EEG revealed left frontotemporal periodic lateralized epileptiform discharges (fig. 2). A repeat lumbar puncture at day 3 was within normal limits. Bacteriological, viral serological (including herpes simplex virus PCR) workup, immunologic parameters as well as toxicology screen revealed no abnormal findings. While the confusion progressively waned, EPC persisted despite several antiepileptic drug trials (phenytoin, valproic acid, carbamazepine, clobazam, lamotrigine). A probable diagnosis of HPC was eventually made when urine coproporphyrins and fecal total porphyrins returned to twice the normal range (even when testing was made 9 days after admission while the patient was improving). These abnormal results could not be explained by other conditions which have previously been associated with secondary coproporphyrinurias such as abuse of toxic substances, liver diseases, malignancies, diverse hematological diseases, etc. [6]. Over the last 3 years, the patient has continued to present non-disabling EPC (manifesting only as very low-amplitude right hand myoclonic jerks) and has had a total of four tonicclonic seizures in the context of alcohol consumption. He remains with mild memory problems and is currently treated with levetiracetam. On the last brain MRI (2 years after initial setting), T2 signal changes had decreased significantly (fig. 3).

Case 2

A 30-year-old man, known only for a generalized anxiety disorder, was brought to the emergency room on November 16, 2011, in convulsive status epilepticus preceded over the last 3 days by nausea, vomiting and headaches. Initial management included intravenous benzodiazepines and phenytoin followed by intubation and a perfusion of midazolam and propofol. The patient then evolved to EPC as he presented continuous left hand and mouth myoclonic jerks, very rarely associated with altered consciousness. EEG (fig. 4) showed 
diffuse slowing, sometime associated with right frontotemporal periodic lateralized epileptiform discharges. MRI disclosed right hemispheric gyriform increased signal on T2weighted images, restricted diffusion on DWI/ADC images and mild midline shift to the left. Brain PET revealed focal hypermetabolism over the right frontal and temporal lobes, and to a lesser extent in the right occipital region. Two lumbar punctures were normal. As in the first patient, bacteriological, viral serological workup as well as immunologic parameters failed to disclose a plausible cause. His condition eventually worsened, with decreased level of consciousness leading to intubation, despite large spectrum antibiotics, acyclovir, several antiepileptic drug trials (phenobarbital, levetiracetam, lacosamide, topiramate, vigabatrin, gabapentin) and immunotherapy (intravenous immunoglobulins, plasma exchanges). Diagnosis of porphyria was made when results from urine, fecal and serum porphyrins returned elevated at 3 weeks after admission. One month and a half after admission and despite hematin therapy and withdrawal of porphyrinogenic drugs, the patient eventually died from brain edema secondary to the status epilepticus, after he had suffered a porphyric attack from an isoflurane trial. Later, genetic testing confirmed HCP with a rare homozygous missense G189S mutation in the coproporphyrinogen III oxidase gene.

\section{Discussion}

Porphyrias are uncommon, complex metabolic disorders caused by deficiencies in the activities of the seven out of eight enzymes of the heme biosynthetic pathway [3]. They are generally subdivided into acute and non-acute porphyrias on the basis of their major clinical manifestations [3]. The acute porphyrias are well-defined genetic disorders of heme biosynthesis characterized by acute life-threatening attacks of nonspecific neurologic symptoms. These acute porphyrias are comprised of acute intermittent porphyria (AIP), HCP, variegate porphyria (VP) and 5-aminolevulinic acid dehydratase porphyria (ADP) in which AIP is the most frequent type. The combined prevalence of the acute porphyrias is approximately 5 cases per 100,000 persons, they are more common in women than in men, and often generally develop during adult life. Acute porphyric attacks can be exacerbated by a variety of factors, including porphyrinogenic drugs, alcohol, endogenous hormones particularly progesterone, pregnancy, cigarette smoking, metabolic stress induced by infections or surgery and reduced caloric intake [1]. Misdiagnoses of porphyrias are common because the signs and symptoms of acute attacks are variable and may mimic many other diseases. They can present with acute neurovisceral attacks, which may be accompanied by skin lesions in HCP and VP. Abdominal pain [1], reported approximately in 85-95\% of patients, is often accompanied by nausea, vomiting, constipation and diarrhea. Other symptoms include acute psychiatric symptoms, seizures, tachycardia and hypertension, and peripheral neuropathy.

Seizures [1] occur in approximately $10-20 \%$ of patients with symptomatic porphyrias. The most common types of seizures reported in the literature consist of complex partial or tonic-clonic seizures. Status epilepticus is less common, having been reported on five instances only. A summary of these previously reported cases is presented in table 1 [6-10] along with our cases. All were adult patients. Status epilepticus was part of the initial presentation for all subjects with the presence of visceral symptoms in two. Pregnancy was a precipitating factor in two. The type of status varied greatly from convulsive status epilepticus to non-convulsive status epilepticus, complex partial status and EPC. EEG revealed non-specific periodic discharges or rhythmic focal activity. Non-surprisingly, confirmation of diagnosis led to modification of the treatment regimen with good outcome 
for all patients except one (case 2). Out of the previously five reported cases, 3 patients had AIP, 1 patient had VP and 1 had an unknown type of acute porphyria, while both of our patients had HCP.

Current understanding of the pathogenesis of seizures suggests the hepatic production of a neurotoxic substance, presumably ALA [a $\gamma$-aminobutyric acid (GABA) analogue] and/or PBG which may interact with GABA or glutamate receptors [2]. A combination of endothelial dysfunction, hypoperfusion, and vasoconstriction in this setting of neurotoxicity can lead to a compromise of the blood-brain barrier and brain edema [11]. MRI may help detect changes occurring in the brain at the time of the acute attack though lesions are non-specific (cortically and/or subcortically, anterior or posterior, without or with mild enhancement, generally but not always reversible) [11,12]. Seizures, when they occur, are a therapeutic challenge because most AEDs (phenobarbital, carbamazepine, clonazepam, phenytoin, primidone, ethosuximide, valproic acid, lamotrigine, felbamate, tiagabine, topiramate) may exacerbate attack of acute porphyria [13]. Drugs reported to be relatively safe include gabapentin [6, 8, 14], levetiracetam [7], and possibly oxcarbazepine [15].

\section{Conclusion}

Acute porphyrias may be a cause of new onset convulsive status epilepticus and EPC. Although rare, their recognition is important as it modifies significantly patient management and probably their outcome.

\section{References}

-1 Anderson KE, Bloomer JR, Bonkovsky HL, Kushner JP, Pierach CA, Pimstone NR, Desnick RJ:

Recommendations for the diagnosis and treatment of the acute porphyrias. Ann Intern Med 2005;142:439450.

2 Balwani M, Desnick RJ: The porphyrias: advances in diagnosis and treatment. Blood. DOI: 10.1182/blood2012-05-423186.

-3 Schneider-Yin X, Harms J, Minder EI: Porphyria in Switzerland, 15 years experience. Swiss Med Wkly 2009;139:198-206.

4 Bylesjö I, Forsgren L, Lithner F, Boman K: Epidemiology and clinical characteristics of seizures in patients with acute intermittent porphyria. Epilepsia 1996;37:230-235.

-5 Ghosh S, Chaudhury PK, Goswami HK: An analysis of six cases of acute intermittent porphyria (AIP). Indian J Psychiatry 2006;48:189-192.

6 Hift R, Meissner P: Miscellaneous abnormalities in porphyrin production and disposal; in Kadish KM, Smith KM, Guilard R (eds): Medical aspect of porphyrins. The porphyrin handbook. San Diego, Elsevier Science, 2003, vol 14, pp 151-165.

7 Yandel ML, Watters MR: Treatment of complex partial status epilepticus unmasking acute intermittent porphyria in a patient with resected anaplastic glioma. Clin Neurol Neurosurg 1995;97:261-263.

-8 Zaatreh MM: Levetiracetam in porphyric status epilepticus: a case report. Clin Neuropharmacol $2005 ; 28: 243-244$

-9 Pandey CK, Singh N, Bose N, Sahay S: Gabapentin and propofol for treatment of status epilepticus in acute intermittent porphyria. J Postgrad Med 2003;49:285.

-10 Engelhardt K, Trinka E, Franz G, Unterberger I, Spiegel M, Beer R, Pfausler B, Kampfl A, Schmutzhard E: Refractory status epilepticus due to acute hepatic porphyria in a pregnant woman: induced abortion as the sole therapeutic option? Eur J Neurol 2004;11:693-697.

$\checkmark 11$ Weinzierl A, Brezinka C, Engelhardt K: Unusual manifestation of acute hepatic porphyria in pregnancy. Fetal Diagn Ther 2007;22:136-138.

12 Dahlgren M, Khosroshahi A, Stone JH: A 22-year-old woman with severe headaches, vomiting, and tonicclonic seizures. Arthritis Care Res (Hoboken) 2011;63:165-171.

13 Kang S-Y, Kang J-H, Choi JC, Lee JS: Posterior reversible encephalopathy syndrome in a patient with acute intermittent porphyria. J Neurol 2010;257:663-664. 


\begin{tabular}{l|l}
\hline DOI: $10.1159 / 000353279$ & $\begin{array}{l}\text { C } 2013 \text { S. Karger AG, Basel } \\
\text { www.karger.com/crn }\end{array}$ \\
\hline
\end{tabular}

Tran et al.: Acute Porphyria Presenting as Epilepsia Partialis Continua

14 Ventura P, Cappellini MD, Rocchi E: The acute porphyrias: a diagnostic and therapeutic challenge in internal and emergency medicine. Intern Emerg Med 2009;4:297-308.

15 Hahn M, Gildemeister OS, Krauss GL, Pepe JA, Lambrecht RW, Donohue S, Bonkosky HL: Effects of new anticonvulsant medications on porphyrin synthesis in cultured liver cells: potential implications for patients with acute porphyria. Neurology 1997;49:97-106.

16 Gaida-Hommernick B, Rieck K, Runge U: Oxcarbazepine in focal epilepsy and hepatic porphyria: a case report. Epilepsia 2001;42:793-795. 


\section{Case Reports in Neurology}

\begin{tabular}{l|l}
\hline Case Rep Neurol 2013;5:116-124 & \\
\hline DOI: 10.1159/000353279 & $\begin{array}{l}\text { @ 2013 S. Karger AG, Basel } \\
\text { www.karger.com/crn }\end{array}$ \\
\hline
\end{tabular}

Tran et al.: Acute Porphyria Presenting as Epilepsia Partialis Continua

Table 1. Summary of clinical, imaging, and encephalographic features of previously reported cases and our cases

\begin{tabular}{|c|c|c|c|c|c|c|c|}
\hline & \multicolumn{5}{|l|}{ In the literature } & \multicolumn{2}{|l|}{ Our patients } \\
\hline & Case 1 & Case 2 & Case 3 & Case 4 & Case 5 & Case 6 & Case 7 \\
\hline Age, years & 42 & 48 & 26 & 22 & 22 & 49 & 30 \\
\hline Gender & female & female & female & female & female & male & male \\
\hline $\begin{array}{l}\text { Past } \\
\text { medical } \\
\text { history }\end{array}$ & $\begin{array}{l}\text { epilepsy related to } \\
\mathrm{LF} \text { astrocytoma } \\
\text { (resected } 5 \mathrm{y} \\
\text { earlier) }\end{array}$ & $\begin{array}{l}\text { AIP diagnosed at } \\
\text { age } 20 \text { after } \\
\text { refractory SE; } 3 \\
\text { other SE } \\
\text { subsequently }\end{array}$ & $\begin{array}{l}\text { none but family } \\
\text { history of AIP }\end{array}$ & $\begin{array}{l}\text { normal first } \\
\text { pregnancy }\end{array}$ & $\begin{array}{l}\text { normal first } \\
\text { pregnancy }\end{array}$ & Berger's disease & $\begin{array}{l}\text { generalized anxiety } \\
\text { disorder }\end{array}$ \\
\hline $\begin{array}{l}\text { Exacerbat- } \\
\text { ing factors }\end{array}$ & $\begin{array}{l}\text { surgery for } \\
\text { presumed } \\
\text { cholecystectomy }\end{array}$ & $\begin{array}{l}\text { leg deep venous } \\
\text { thrombosis }\end{array}$ & alprazolam & second pregnancy & $\begin{array}{l}\text { second } \\
\text { pregnancy }\end{array}$ & $\mathrm{ROH}$ & - \\
\hline $\begin{array}{l}\text { Visceral } \\
\text { symptoms }\end{array}$ & $\begin{array}{l}\text { abdominal } \\
\text { discomfort, } \\
\text { anorexia, episodic } \\
\text { dark urine }\end{array}$ & - & - & - & - & - & nausea, vomiting \\
\hline $\begin{array}{l}\text { Neurologi- } \\
\text { cal } \\
\text { symptoms }\end{array}$ & $\begin{array}{l}\text { delirium, complex } \\
\text { partial SE }\end{array}$ & $\begin{array}{l}\text { refractory complex } \\
\text { partial SE }\end{array}$ & $\begin{array}{l}\text { confusion, } \\
\text { quadriparetic, } \\
\text { labored respiration, } \\
\text { convulsive SE }\end{array}$ & $\begin{array}{l}\text { delirium, GTC } \\
\text { seizure } \rightarrow \text { convulsive } \\
\text { SE }\end{array}$ & $\begin{array}{l}\text { psychiatric } \\
\text { symptoms GTC } \\
\text { seizures } \rightarrow \\
\text { convulsive SE }\end{array}$ & $\begin{array}{l}\text { confusion, one GTC } \\
\text { seizure } \rightarrow \text { EPC }\end{array}$ & $\begin{array}{l}\text { headache, } \\
\text { confusion, } \\
\text { convulsive SE } \rightarrow \\
\text { EPC } \rightarrow \text { NCSE }\end{array}$ \\
\hline $\begin{array}{l}\text { Seizure } \\
\text { description }\end{array}$ & $\begin{array}{l}\text { staring, altered } \\
\text { consciousness, } \\
\text { complex motor } \\
\text { behavior }\end{array}$ & $\begin{array}{l}\mathrm{R} \text { head deviation, } \mathrm{R} \\
\text { facial clonic jerks, } \mathrm{R} \\
\text { arm tonic-clonic } \\
\text { activity, } 20-120 \mathrm{~s} \text {, } \\
\sim 15 \text { to } 20 / \mathrm{h}\end{array}$ & $\begin{array}{l}\text { R facial and upper } \\
\text { limb twitching (day } \\
12 \text { ) } \rightarrow \text { convulsive SE } \\
\text { (day 14) }\end{array}$ & $\begin{array}{l}\text { loss of } \\
\text { consciousness, } R \text { leg } \\
\text { clonic activity } \rightarrow \text { R } \\
\text { arm } \rightarrow \text { GTC activity, } \\
2-3 \text { min } \rightarrow \\
\text { convulsive SE }\end{array}$ & - & $\begin{array}{l}\text { tonic-clonic seizure } \\
\text { evolving into } \\
\text { continuous right } \\
\text { hand myoclonic } \\
\text { jerks }\end{array}$ & $\begin{array}{l}\text { four GTC seizures } \\
\rightarrow \text { NCSE with the L } \\
\text { hand and mouth } \\
\text { jerks, rarely } \\
\text { associated with } \\
\text { altered } \\
\text { consciousness }\end{array}$ \\
\hline MRI/scan & $\begin{array}{l}\text { unchanged } \\
\text { postoperative } \\
\text { encephalomalacia }\end{array}$ & $\begin{array}{l}\text { CT: possible L } \\
\text { hemisphere edema }\end{array}$ & - & $\begin{array}{l}\text { biF } \uparrow \text { diffusion } \\
\text { coefficient }\end{array}$ & - & biT T2/FLAIR & $\begin{array}{l}\mathrm{R} \text { hemispheric } \\
\text { gyriform T2 } \\
\text { changes + diffusion } \\
\text { restriction; mild L } \\
\text { midline shift }\end{array}$ \\
\hline EEG & $\begin{array}{l}\text { bursts of spikes, } \\
\text { poly-spikes, sharp } \\
\text { waves, } \\
\pm \text { sharp/slow } \\
\text { complexes over } \\
\text { biFT leads L R }\end{array}$ & $\begin{array}{l}\text { L>R slowing; during } \\
\text { seizures: rhythmic } \\
\text { L FT theta activity }\end{array}$ & - & $\begin{array}{l}\text { during seizures: } \\
\text { rhythmic L F slow } \\
\text { activity } \rightarrow \text { both } \\
\text { hemispheres }\end{array}$ & - & L F PLEDs & $\begin{array}{l}\text { severe diffuse } \\
\text { slowing; R FT } \\
\text { PLEDs }\end{array}$ \\
\hline $\begin{array}{l}\text { Treatment } \\
\text { before } \\
\text { diagnosis }\end{array}$ & $\begin{array}{l}\text { PHT, CBZ, LZP, } \\
\text { Pentobarbital }\end{array}$ & - & - & LZP, PHT, LEV & OXC, LEV, PHT & $\begin{array}{l}\text { ayclovir, PHT, VPA, } \\
\text { CBZ, CLB, LTG }\end{array}$ & $\begin{array}{l}\text { antibiotics, } \\
\text { acyclovir, plasma } \\
\text { exchange, IG, Pb, } \\
\text { propofol, LEV, LCM, } \\
\text { TPM, VGB, }\end{array}$ \\
\hline $\begin{array}{l}\text { Treatment } \\
\text { after } \\
\text { diagnosis }\end{array}$ & $\begin{array}{l}\text { high carbohydrate } \\
\text { diet, hematin, GPN }\end{array}$ & $\begin{array}{l}\text { hematin; GPN; OXC } \\
\rightarrow \text { LEV + Mg }\end{array}$ & $\begin{array}{l}\text { hematin, propofol, } \\
\text { GPN }\end{array}$ & $\begin{array}{l}\text { GPN, LZP, high } \\
\text { carbohydrate intake, } \\
\text { hematin, abortion }\end{array}$ & abortion & LEV & $\begin{array}{l}\text { hematin, (VGB, } \\
\text { LEV, LCM) } \rightarrow \text { GPN, } \\
\text { plasma exchange, } \\
\text { IG }\end{array}$ \\
\hline Outcome & $\begin{array}{l}\text { no further delirium } \\
\text { over next } 2 \text { years; } \\
\text { modest } \downarrow \text { in seizure } \\
\text { frequency }\end{array}$ & $\begin{array}{l}\text { no further seizures } \\
\text { over next } 8 \text { months } \\
\text { of FU }\end{array}$ & $\begin{array}{l}\text { convulsions } \\
\text { stopped, alert, able } \\
\text { to walk with } \\
\text { support (day 16) }\end{array}$ & $\begin{array}{l}\text { no futher convulsion } \\
\text { after abortion }\end{array}$ & $\begin{array}{l}\text { no further } \\
\text { seizures as well } \\
\text { as attack of } \\
\text { hepatic } \\
\text { porphyria over } \\
\text { next } 2 \text { years of } \\
\text { FU }\end{array}$ & $\begin{array}{l}\text { mild memory } \\
\text { deficits, persisting } \\
\text { but non-disabling R } \\
\text { hand EPC; } 1 \mathrm{GTC} \\
\text { seizure and } 1 \text { cluster } \\
\text { of } 3 \mathrm{GTC} \text { seizures in } \\
\text { the setting of ROH } \\
\text { intake over last } 3 \\
\text { years }\end{array}$ & deceased \\
\hline $\begin{array}{l}\text { Type of } \\
\text { porphyria }\end{array}$ & AIP & AIP & AIP & VP & $\begin{array}{l}\text { acute hepatic } \\
\text { porphyria }\end{array}$ & НCP & НCP \\
\hline Reference & $\begin{array}{l}\text { Yandel and Watter } \\
\text { (1995) [7] }\end{array}$ & $\begin{array}{l}\text { Zaatreh et al. } \\
(2005)[8]\end{array}$ & $\begin{array}{l}\text { Pandey et al. (2003) } \\
\text { [9] }\end{array}$ & $\begin{array}{l}\text { Engelhardt et al. } \\
\text { (2004) [10] }\end{array}$ & $\begin{array}{l}\text { Weinzierl et al. } \\
\text { (2007) [11] }\end{array}$ & & \\
\hline
\end{tabular}




\section{Case Reports in Neurology}

\begin{tabular}{l|l}
\hline Case Rep Neurol 2013;5:116-124 & \\
\hline DOI: $10.1159 / 000353279$ & $\begin{array}{l}\text { ○ 2013 S. Karger AG, Basel } \\
\text { www.karger.com/crn }\end{array}$ \\
\hline
\end{tabular}

Tran et al:: Acute Porphyria Presenting as Epilepsia Partialis Continua

$\mathrm{L}=$ Left; $\mathrm{R}$ = right; $\mathrm{F}$ = frontal; $\mathrm{T}$ = temporal; $\mathrm{PHT}$ = phenytoin; $\mathrm{CBZ}$ = carbamazepine; $\mathrm{Pb}=$ phenobarbital; $\mathrm{LZP}=$ lorazepam; $\mathrm{GPN}$ = gabapentin; $\mathrm{SE}=$ status epilepticus;

NCSE = non-convulsive status epilepticus; PLEDs = periodic lateralized epileptiform discharges; GTC = generalized tonic-clonic; IG = immunoglobulin.
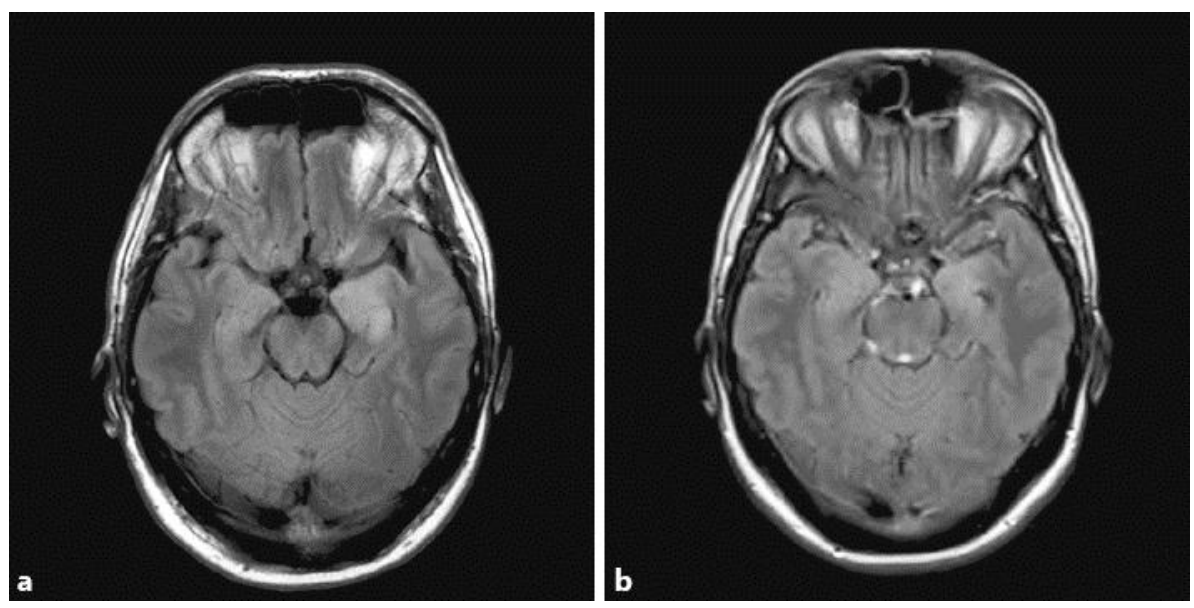

Fig. 1. FLAIR sequence showing hyperintensity over both mesial temporal structures (a), with mild incomplete regression after 2 years (b). 


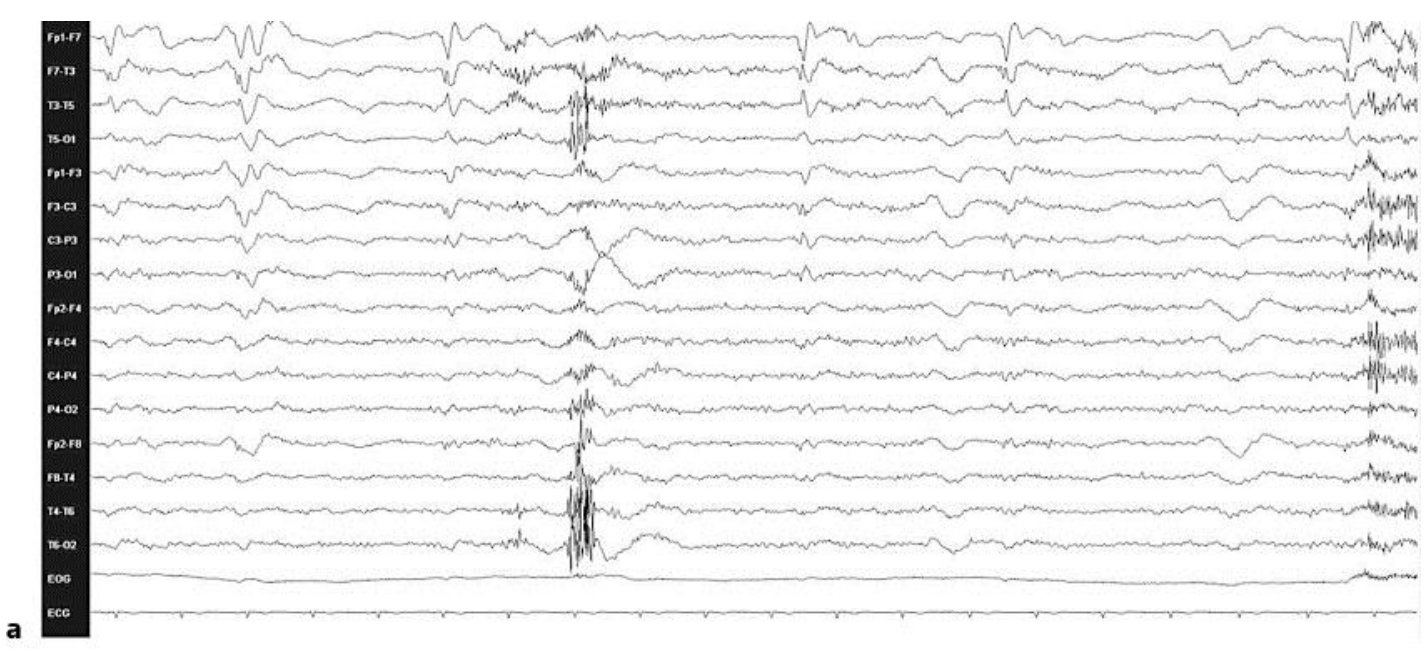

Tran et al.: Acute Porphyria Presenting as Epilepsia Partialis Continua

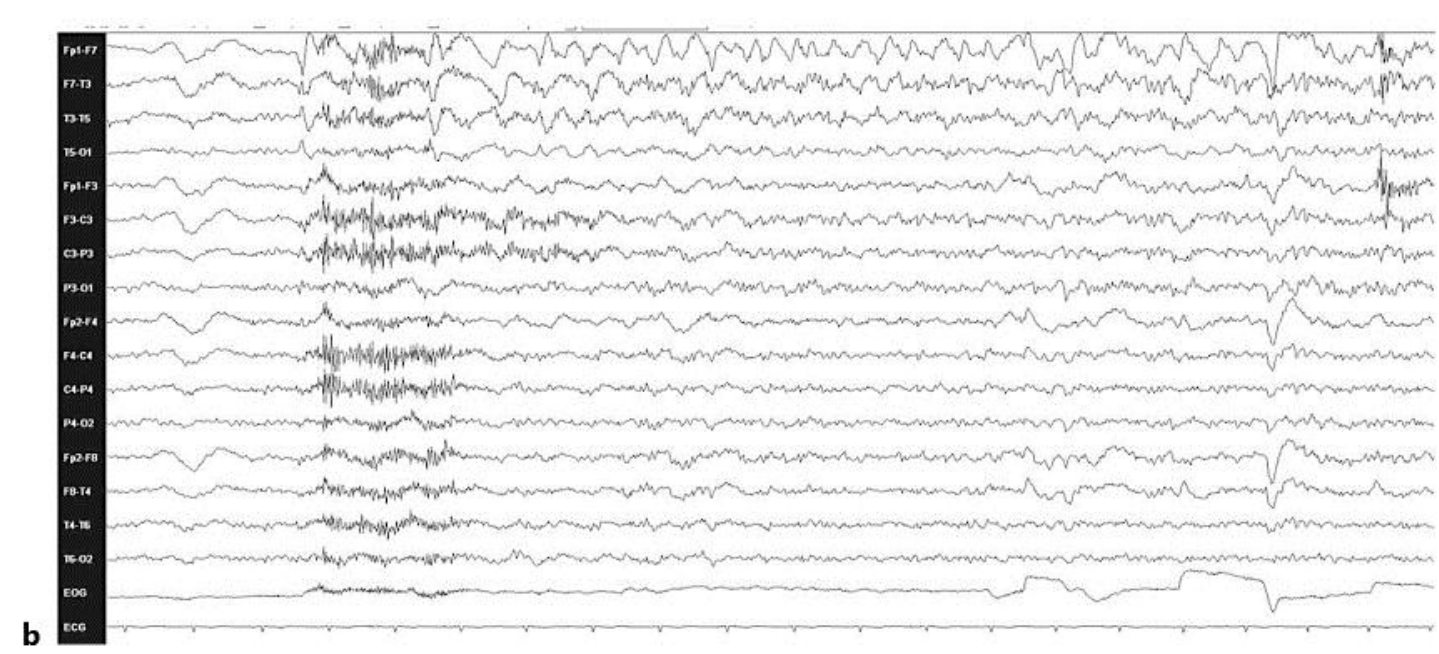

Fig. 2. a EEG with left frontotemporal periodic lateralized epileptiform discharges. $\mathbf{b}$ Left frontotemporal periodic discharges evolving into rhythmic slow activity discharge most prominent over the left frontotemporal region $(\mathrm{HFF}=35 \mathrm{~Hz} ; \mathrm{LFF}=1 \mathrm{~Hz})$. 


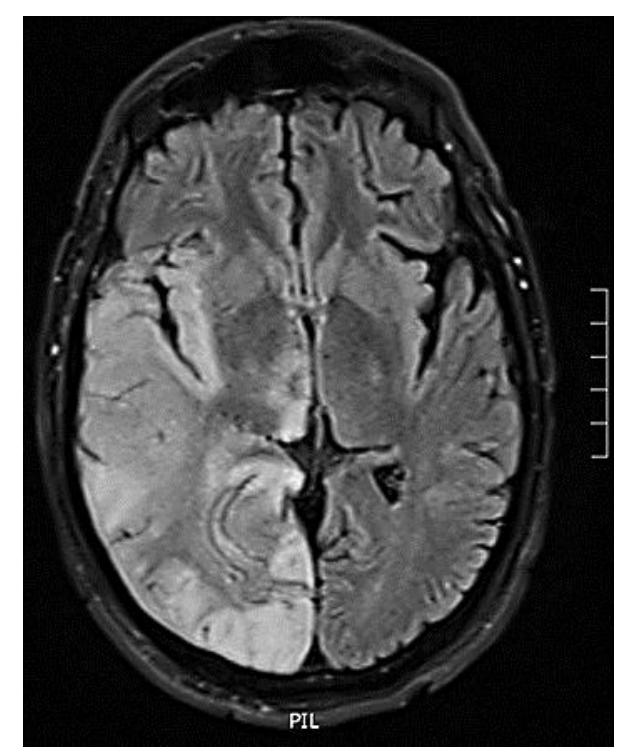

Fig. 3. FLAIR image showing right hemispheric gyriform hyperintense signal changes.

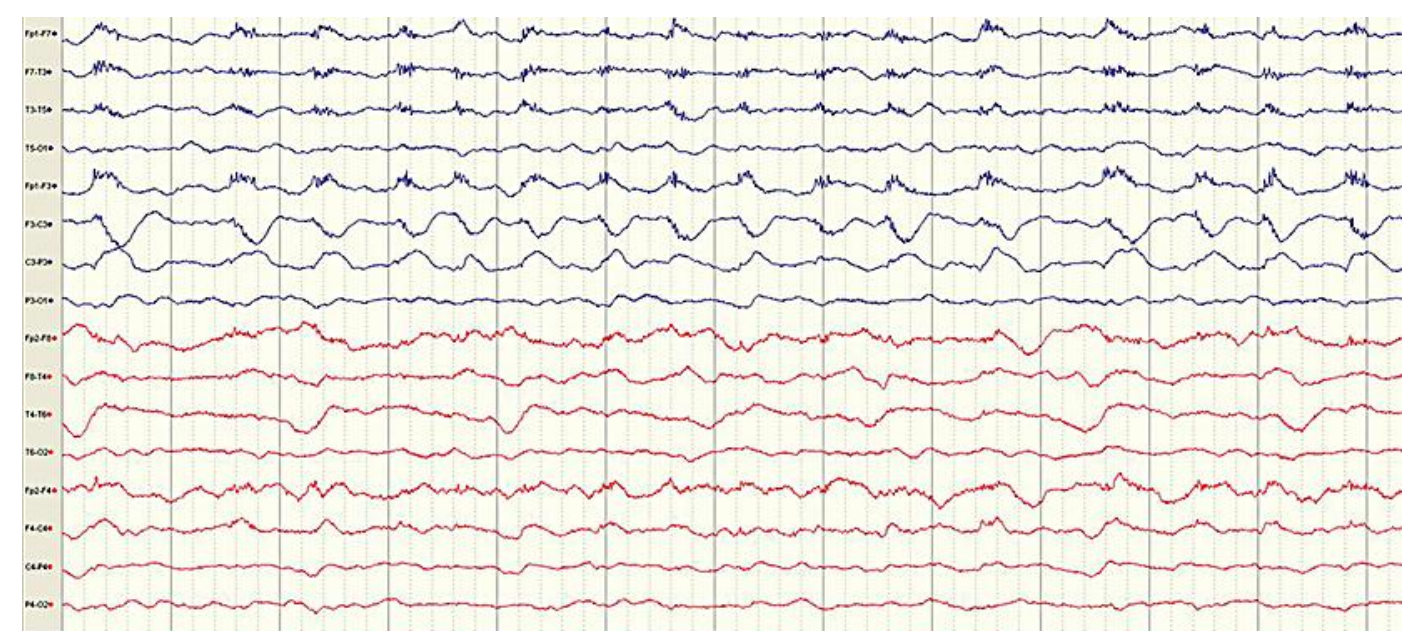

Fig. 4. EEG showing diffuse slowing activity, right frontal subtle/blunted periodic lateralized epileptiform discharges and left-sided muscle artifacts due to left facial jerks. 